\title{
International cooperation and health policy implementation in a post-conflict situation: the case of East Timor
}

\section{Luiz Eduardo Fonseca}

Advisor for Africa and Portuguese-speaking Countries, Centro de Relações Internacionais/Fiocruz. Avenida Brasil, 4365

21040-900 - Rio de Janeiro - RJ - Brazil lef@fiocruz.br

\section{Celia Almeida}

Researcher and professor, Escola Nacional de Saúde Pública Sergio Arouca/Fiocruz. Rua Leopoldo Bulhões, 1480 21041-210 - Rio de Janeiro - RJ - Brazil calmeida@ensp.fiocruz.br

Received for publication in July 2013.

Approved for publication in August 2014.

Translated by Peter Lenny.
FONSECA, Luiz Eduardo; ALMEIDA, Celia. International cooperation and health policy implementation in a postconflict situation: the case of East Timor. História, Ciências, Saúde - Manguinhos, Rio de Janeiro, v.22, n.1, jan.-mar. 2015. Available at: http://www.scielo.br/hcsm.

\section{Abstract}

This study centers on relationships among national and international actors in preparation of the first health policy document for East Timor, under the United Nations transitional administration, between 1999 and 2002. International cooperation support for the health system rehabilitation process during the postconflict period is analyzed as part of reconstruction of the State in parallel with construction of the country's political and institutional framework. Knowledge, ideas, "ways of doing," and induced and accepted practices permeate an interplay of power relationships that condition both national political alliance-building and the architecture of international aid, pointing to input to a discussion of how these mechanisms interact at different conjunctures and times in different negotiating frameworks.

Keywords: international cooperation; post-conflict situation; health policies; East Timor. 
In countries where there are armed conflicts, the health sector is directly affected by loss of life, physical and mental harm, total or partial destruction of health facilities and disruption of health system infrastructure (Waters, Garret, Burnham, 2007). Once peace operations are in place in these countries, a transitional "post-conflict" period ensues, where the international community is mobilized to support social and economic reconstruction, in a process involving a range of different actors.

The subject of policy making has been explored by public health studies, and situations of conflict and post-conflict, by international relations. Few studies cover both areas, however. This study prioritizes a historical focus in contextualizing facts and events, to emphasize the relationships that develop during this process. In addition, its case study approach rests on a systematic, qualitative methodology in which information gathering draws on extensive bibliographical research and document analysis.

This article examines the involvement of different negotiating spaces in preparing the health policy proposal document for East Timor during the period of post-conflict and transition to the country's new government. Special emphasis is given to the forms of consultation, monitoring and participation used in preparing and implementing this proposal, as factors conditioning both the actors present in the process and the content of the policy. The power relationships and the methods by which power was exercised within the health sector during the United Nations transitional administration period are discussed. This yielded evidence of the dialectical relationship between donors and recipients, which was expressed concretely in the architecture of foreign aid to East Timor between 1999 and 2002, conditioned by the situation of conflict and post-conflict, and mediated by foreign organizations through technical cooperation mechanisms.

\section{Historical context}

The island of Timor is the most easterly of the islands belonging to the Sunda archipelago, adjacent to Sumatra and Java (O'Connor, 2007). The first Portuguese settlement was established on the easterly side of the Malay archipelago, on the island of Solar, in 1566, which gave rise to an "admixed" population (Taylor, 1999, p.3). These people of "mixed race heritage" were the first "Portuguese" to settle on the island, in around 1640, when Timorese territory was controlled on the basis of a strategic political and cultural alliance to defend the area from invasion by other foreigners.

In 1859, negotiations between Portugal and Holland resulted in a territorial treaty that drew the present borders East Timor. Afonso de Castro took part in these negotiations and was appointed the first governor of "Portuguese Timor," having introduced the cultivation of coffee, sugarcane and cotton (Schouten, 2007), although sandalwood continued for many years to be one of the country's main export products.

Timor's reino (kingdom) divisions and their authority were respected during the Portuguese colonial period on a policy of "non-interference" in exchange for payments of fintas (taxes). In 1912, the fintas levy led to the Dom Boaventura (or Manufai) Rebellion, which was energetically repressed by the Portuguese, who introduced a new colonial administrative structure based on sucos (districts), replacing the reinos. At this point, a series of forced 
"Europeanizing" civilizing ideas (Schouten, 2007) were fostered by the introduction of new standards of housing and living conditions, and police, health and education services, and the insistence on Western dress. Although, the Portuguese experience in East Timor was a failure in economic and social terms, it should be acknowledged that these (civilizing) elements were important in forming and shaping the Timorese elite (Taylor, 1999).

In 1970, East Timor had an admixed elite which had adopted Portuguese ways and close ties to the Catholic Church, and carried out administrative functions at the provincial level, while the rest of the population remained rooted in local traditions and leaderships. Levels of literacy were low, while birth, infant mortality and contagious infectious-disease rates were high. The public sanitation and transport systems were precarious, and $60 \%$ of schools were run by Catholic missionaries and designed primarily for assimilated and mixed-race Timorese (less than $10 \%$ of the population were students). Secondary schools were first established in the 1960s. In 1970, there were two Timorese students studying at university abroad; this number increased to 39 in 1975 (Taylor, 1999). Administrative functionaries were recruited from a small literate elite, while senior administrative positions (doctors, teachers, commanding officers, heads of government departments and governors) were reserved to the Portuguese.

The East Timor Health Service, set up in 1918, included four civil healthcare facilities, one infirmary and one military hospital. Most cases were treated in the capital, Dili. In the period following Second World War, the health system was improved with the support of the Portuguese armed forces, which were responsible for providing most healthcare services and for training health personnel. In the 1950s the diseases most frequently reported and causing the highest number of deaths were malaria, tuberculosis and diarrhea. From 1946 until the 1970s, the same department was responsible for health care and welfare assistance in East Timor (Agência..., 1966).

\section{East Timor's first political parties and short-lived independence}

East Timor's first political parties were formed over a short period in April and May 1974, following Portugal's Carnation Revolution (Revolução dos Cravos) of April 25 (Anversa, s.d.). The Timorese Democratic Union (União Democrática Timorense - UDT), the first to be legalized, was a conservative grouping that advocated progressive, but orderly, selfdetermination based on a possible "federation" to include Portugal. The second party to be formed was the Timorese Social Democratic Association (Associação Social Democrata Timorense - ASDT), whose members rejected colonialism and proposed a gradual process of independence preceded by administrative, economic, social and political reforms. The third party to be set up was the Timorese Popular Democratic Association (Associação Popular e Democrática Timorense, Apodeti), which favored a situation of social and administrative autonomy within the Indonesian confederation, as enjoyed by Bali.

In the mid-1970s, at the height of the Cold War, the possibility of an independent East Timor caused a stir in regional diplomatic channels, coinciding as it did with the decolonization of Portugal's colonies in Africa. Indonesia, under the dictatorial Sukarno government, had been hatching a plan since the 1950s to annex former Dutch territories (the Dutch East Indies) and, for its own ulterior motives, supported the independence of 
East Timor. In 1962, Indonesia even provided a base in Jakarta to the so-called "Bureau of Liberation of the Timor Republic, claimed to have established a government in exile" (Taylor, 1999, p.21). These "integrationist" movements, which wanted the whole island of Timor integrated territorially, managed to destabilize the political situation in Portuguese Timor.

In early 1970s, president Sukarno - who had helped found The Non-Aligned Movement in 1955 - diplomatically adopted a position of non-interference in relation both to Portuguese sovereignty over Timor and to a possible independent Timorese government. Australia, meanwhile, fearing regional instability that would follow the rise of left-wing separatist movements, positioned itself strategically as an observer.

Against this backdrop of events, in 1974, a dissident group from the ASDT dissatisfied with the party's organizational structure and aims, set up the Revolutionary Front for an Independent East Timor (Frente Revolucionária do Timor-Leste Independente, FRETILIN) proposing mass mobilization and a rapid de facto process of independence, including control over the State and institutional changes (Machado, s.d.). The Front was formed by young militants who wanted a more decentralized party organization which would delegate functions to district subcommittees responsible for mobilizing the rural population. The Front incorporated Timorese cultural elements into its political platform and, alongside Portuguese, adopted Tétum as "the language of independence," strategically retrieving the meaning of some local words and becoming known as a maubere (peasant) movement. The new party grew and assumed the position of a popular front and, by the end of 1974 had become the largest political organization in East Timor, forming coalitions with other parties (Anversa, s.d.).

In May 1975, the Portuguese Decolonization Commission held a conference in Macao to discuss the process of decolonization. All the Timorese parties were invited, together with civil and military representatives of the Portuguese government in East Timor and representatives from Indonesia. FRETILIN refused to attend. That same month, UDT leaders announced that they were leaving the FRETILIN coalition. The Front introduced "Revolutionary Brigades" in rural areas in order to establish education and healthcare activities, which increased their popularity and strengthened their political organization (Taylor, 1999, p.47).

\section{Short-lived independence}

Still in 1975, sectors of the UDT began openly to advocate annexation by Indonesia, and called for "communists" to be expelled from East Timor. The UDT-Apodeti coalition delivered an ultimatum to the Portuguese authorities, demanding the formation of a transitional government that excluded FRETILIN, which immediately reacted by calling for public support. Military reinforcements sent from Lisbon were insufficient to maintain order. Timorese military personnel at two key Portuguese garrisons declared their support for FRETILIN and occupied Portuguese army headquarters, making it easier at this point for FRETILIN to obtain a victory. As a result, Suharto declared for the first time that an independent East Timor was "not viable." Claiming that FRETILIN was a communist party, he gave direct support to Apodeti and the UDT, resulting in a vast migratory exodus on the borders with West Timor and the hasty departure of the colonial authorities (Machado, s.d.). 
Under these circumstances, FRETILIN, with the support of the majority of the population, proclaimed the independence of the Democratic Republic of East Timor on November 28, 1975. They now found themselves responsible for managing a State now with $80 \%$ fewer civil servants. There were also no doctors, engineers or other professionals capable of helping to reorganize the country. Immediately after the declaration of independence, Ramos Horta, then minister of Foreign Affairs, went to New York to seek support from the international community through the United Nations. At the same time, Indonesia intensified its efforts to destabilize the region by increasing its anti-communist propaganda and by initiating a military intervention - Operasi Komodo - on the borders of West Timor (Anversa, s.d.).

\section{Indonesian invasion and domination, Timorese resistance and adhesion}

Ten days after independence was declared, over 20,000 Indonesian soldiers entered East Timor by land and sea. FRETILIN was unable to resist and there were massacres, looting and stealing from private homes and public buildings. On July 16, 1976, Suharto proclaimed East Timor the $27^{\text {th }}$ Province of the Republic of Indonesia and appointed a Timorese from Apodeti as governor. Members of FRETILIN, with the support of the population, the liurai and suco leaders, launched a resistance movement. The Front set up a military wing called the Armed Forces for the National Liberation of East Timor (FALINTIL), which until the 1990s, waged a war of national liberation against Indonesia.

Since the time of the invasion, the Catholic Church had moved closer to the Timorese political and cultural resistance movement in its fight for independence and expanded its contacts within the rural community. Conversions to Catholicism rose from 32\% in 1975 to 78\% in 1984 (Anversa, s.d.). The Church opened two private universities, where many opponents of the Indonesian regime studied.

In 1979, Alexandre Xanana Gusmão was elected president of FRETILIN. At that time, there were over 6,800 political prisoners in East Timor, mainly in the prison on the island of Ataúro, and many families began to emigrate to Australia and Portugal (Taylor, 1999). With the support of Ramos Horta, this group of exiles and political refugees abroad organized and began to lobby the international community: denouncing the atrocities committed in East Timor, they called for a political stand on the issue. In March 1983, the Indonesian armed forces and the FALINTIL signed a ceasefire agreement that resulted in Portugal's resuming talks with Indonesia, under the auspices of the United Nations secretary-general, in favor of East Timor's independence (Martin, 2001).

The ceasefire enabled FRETILIN and other Timorese political groups to reorganize and to unify the political struggle for the self-determination of East Timor (Niner, 2000). In 1988, the National Council of Maubere Resistance (Conselho Nacional de Resistência Maubere, CNRM), the first nonpartisan Timorese body, was set up and led by Xanana Gusmão. In 1994, the United Nations and humanitarian and human rights organizations were given access to the East Timor and, in 1996, José Manuel Ramos Horta and Bishop Carlos Felipe Ximenes Belo were awarded the Nobel Peace Prize. In April 1998, a new political pact resulted in the National Timorese Resistance Council (Conselho Nacional de Resistência Timorense, CNRT), formed by FRETILIN and UDT, together with Apodeti and social organizations, including the 
Catholic Church. Elected its chairman, Xanana Gusmão promised to work "for a policy of international dialogue and negotiation" (CNRT, abr. 1998a, p.4) and committed to comply with all United Nations Organization norms and conventions (CNRT, abr. 1998b, 9 abr. 1999). The CNRT fought for a temporary national pact to unify domestic political forces and brought a united voice to dealings with the international community.

In 1998, Suharto was overthrown in Indonesia and the new president Habibie granted greater autonomy to East Timor without relinquishing Indonesia's role in the island's defense and economy. That same year, the United Nations appointed a special representative to East Timor and submitted a constitutional proposal for the territory's self-administration (Martin, 2001).

In April 1999, in Melbourne, Australia, the CNRT held a Strategic Planning Conference for the Rebuilding of East Timor, with the presence of sixty Timorese citizens (many of whom lived abroad) and 35 foreign participants, mostly Australians, with the aim of discussing how to prepare an independent government in East Timor (Pereira, 8 maio 1999). This fiveday meeting received the support of several international agencies and non-governmental organizations (NGOs) and provided a political opportunity to support the CNRT chairman, Xanana Gusmão. The idea was to commit him to a proposal for transition to an independent East Timor, with UN involvement in the process of negotiation with Indonesia, and to the organization of a future transitional government. The CNRT, with the support of participants from the conference, appealed to the international community for the necessary support in this process, while attempting to maintain its own standing in relation to that community, noted for defending the "respect and the will of the people of East Timor" (CNRT, 9 abr. 1999).

In May 1999, the governments of Portugal and Indonesia agreed to submit the territory's independence to a referendum, to be supervised by the UN. Whatever the result, the UN would be responsible for governing the country for a transitional period, thereby guaranteeing the results of the referendum (United..., 25 out. 1999).

\section{The referendum and renewed conflict}

Immediate funding enabled the United Nations Mission in East Timor to be organized very quickly and, in a matter of weeks, 446,666 voters were registered at 200 polling stations around the country. On August 30, 1999, 98.6\% of registered voters went to the polls and on September 4 the official results were announced: a majority of voters (78.5\%) had chosen independence and self-determination for the country (Martin, 2001).

The results were reported internationally, but also marked the beginning of an explosion of violence across Timorese territory. Disgruntled paramilitary groups supported by Indonesia mobilized and, in a week of crazed anger, set about destroying innocent lives and numerous public buildings. On September 15, the UN Security Council recognized the situation of violence and authorized the formation of a multinational force (United..., 25 out. 1999; Kondoch, 2001). Thirteen days later, on September 28, a tripartite meeting of the UN, Portugal and Indonesia guaranteed a UN presence in Timorese territory, a decision firmly supported by the CNRT. On October 25, in Jakarta, the People's Consultative Assembly of Indonesia officially recognized the referendum results. On the same day, the UN Security Council adopted 
Resolution 1272, setting up the United Nations Transitional Administration in East Timor (UNTAET) to administer the territory until such time as the country was able to exercise its right to self-determination and independence freely.

\section{The Indonesian legacy and the healthcare situation}

Indonesia had imposed a policy of forced displacement and settlement and a complex system of public services. In 1999, there were more than one hundred thousand migrants in East Timor (14\% of the population), most of whom were Muslim (Gunn, 2007). The Indonesian government agencies set up service provision in several areas (including health care, education, agriculture, information, commerce, banking, the postal system and defense). However, the Timorese people derived little benefit from private investments up to 1998: investments in industrial production and other non-agricultural areas were minimal, while commerce and other private activities were dominated by non-Timorese - Indonesians and Chinese (Pedersen, Arneberg, 1999).

The Indonesian public administration system maintained the district-based political and administrative structure and introduced two representative bodies elected by popular vote: a District Representative Council and a Provincial Representative Council. It employed thousands of Timorese and created cultural prestige values based on hierarchal positions and sustained by systems of nepotism and corruption. Civil service recruitment was conditional on membership of a pro-Jakarta political party. Although bloated, inefficient and riddled with corruption, this administrative machine expanded the scope of public services and provided greater contact with more up-to-date management methods of monitoring and evaluation, which obliged these services to produce results and submit regular reports (Gunn, 2007).

In this process, education and healthcare deserve special mention. A hierarchal, regional education system was established, as was a - previously non-existent - media apparatus of newspapers, magazines and television. In education, Indonesia sought to introduce Bahasa to replace Portuguese as the language of the media and public institutions (Pedersen, Arneberg, 1999; Gunn, 2007). ${ }^{1}$

East Timor's healthcare system was organized by two institutions: the Regional Health Department (Kanwil) and the Provincial Public Health Service (Dinas Tk.). These provided primary healthcare, on a hierarchal, regional system design. ${ }^{2}$ Significant improvements in health indicators were achieved under this system. ${ }^{3}$

\section{Security and development in a post-conflict situation}

The process of reconstructing East Timor after the violent events that followed the referendum was entirely dependent on funding from the international community, which involved interactions among a range of actors, including donor countries, international organizations, Timorese leaders, and others.

It is important to remember that in situations where the nation-State is fragile and under transitional regimes, the role and responsibilities of external actors increase considerably. Furthermore, foreign donors and administrators are also responsible for setting standards of 
conduct to be followed by all during the period of reconstruction, which ultimately seeks to promote development and thereby surmount conflict (Siitonen, 2010).

This dynamic is consistent with re-establishing the relationship between security and development, as has occurred during the post-Cold War period, when fragile, failed or collapsed States have become a significant issue on the development agenda.

At the beginning of the 1990s, the relationship between reconstruction/development and security - the two founding principles of both the UN and the World Bank - gained renewed importance (Siitonen, 2010; Pereira, 2010). Initial interest in this relationship centered on the UN intervening in a number of countries, basically for humanitarian reasons (as, for example, in Bosnia and Somalia). At the same time, outcomes from the structural adjustments induced in the 1980s by the World Bank and the International Monetary Fund (IMF), and these organizations' strategy shift in the post-Washington consensus period, after repeated criticisms and disastrous results, again underlined the role of the State in development. At the same time, the national security agenda was also changing as a result of the collapse of the bipolar world system: security would not be attained solely by military or diplomatic means (Kaldor, 2006; Richards, 2005).

Emergency foreign aid funding was also observed to expand significantly (Siitonen, 2010, p.43-44). The focus shifted from "humanitarian aid" to "new humanitarianism" (Duffield, 2001), which includes post-conflict assistance and conflict prevention, since - according to official discourse - human security is now seen as a challenge primarily for development (Siitonen, 2010).

At the beginning of the new millennium (after September 11, 2001), it was argued that "fragile States" were privileged targets of the donor community's wider strategy, because of the risk of these States falling easy prey to terrorism and organized crime. It was not just underdevelopment that was dangerous or destabilizing; the development "recipe" had also changed: reconstructing the State was now seen as the key task of any development agenda (OECD/DAC, 2008). The term "fragile States" was criticized and replaced with "fragile situations." Frequently used slogans included: "security is a precondition for development" and "development is the means to achieve security." This underlines the importance of encouraging "transitional regimes," where the role of foreign agents is vital and differs from the usual international aid situations. External donors were considered responsible for supporting national sovereignty, reconstructing institutional frameworks and promoting relations between State and society (or vice-versa), when necessary or in line with their own interests (Siitonen, 2010).

The idea that the "[collective] responsibility to protect" is a "moral imperative" (ICISS, 2001) is one that is embraced by the UN, the Organization for Economic Co-operation and Development and the European Union. This means that "peace-building and development" have become the panacea for all the ills of national development policies in countries affected by war or threatened by internal conflicts (Okumu-Alya, 2010, p.87). More recently, the literature shows that there has been global recognition of the "securitization of development," with emphasis on post-conflict reconstruction.

At the same time, the World Bank's 1990 World Development Report "systematized and prescribed a compensatory model of poverty relief, which became an established framework 
for client States," using proper policies, to put into effect "a process, constructed intellectually and politically, for combating poverty," which had been developed since the 1970s under the leadership of McNamara as the bank's president (Pereira, 2010, p.274). Before this, the World Bank's extra-economic agenda had spoken of "social needs" and "basic needs," not of poverty. The "fight against poverty" - rooted in the bipolar world of the Cold War and introduced into the World Bank by the US government - found fertile soil in which to flourish in the situation that arose after the fall of the Berlin Wall (Pereira, 2010). It was seen as a way to overcome the high "social costs" of macroeconomic structural adjustments. Ever since, World Bank loans have specified goal-focused and compensatory interventions worldwide, significantly increasing the Bank's involvement in post-conflict and emergency situations.

In such cases, the political dimension of the governance model adopted decides the positive or negative outcomes in terms of national governance structure (Brinkerhoff, Brinkerhoff, 2002; Koponen, 2010). As well as a means of resolving conflicts and bringing about social and political reconciliation, this political dimension also includes the modus operandi for the transition, that is to say, it sets out the institutional formats and decision-making mechanisms needed to conduct this process, as well as the role of the main organizations involved in this dynamic.

\section{The transition process: participatory mechanisms and power struggles}

\section{The United Nations}

Although resolution 1272 granted UNTAET the power to exercise political governance authority, it also required the administration to consult and work closely with the Timorese people so as to fulfill its mandate effectively "with a view to developing local democratic institutions" (United..., 26 jan. 2000, p.3). From the outset then, the UN mission in East Timor was assigned two - apparently contradictory - core functions: in the short term, to exercise a centralized mandate, and, in the medium term, to prepare institutions and the East Timorese people for the full exercise of democratic government (Beauvais, 2001). In order to perform this twofold mission, UNTAET had to interact concurrently with Timorese social organizations throughout the territory, as well as with the UN mission structure itself, which was centralized in the capital. In parallel with this, it was to oversee the activities of a range of international organizations, both internal and external to the UN, in East Timor, so as to coordinate both foreign and humanitarian aid, and international cooperation. In 1999, there were around 240 NGOs and civil society organizations working in the country (Downie, 2007).

As a first step to assure Timorese involvement in the transitional administration, the National Consultative Council (NCC) was set up on December 2, 1999 (UNTAET, 2 dez. 1999). The NCC comprised 15 members (11 Timorese and four international representatives). Seven of the Timorese representatives belonged to the CNRT, three were from other parties and one represented the Catholic Church. It soon became obvious that the NCC had more weaknesses than strengths: it did not represent the various national institutions, it had little participation in political decision making, and its key mechanisms were not transparent. 
It was clear to the population that this was a situation where "a foreign power was temporarily assisting a fragile Timorese organization" (Seixas, 2007, p.72), drawing protests from various groups. Just a few months later, UNTAET dissolved the NNC.

In July 2000, two new government bodies were set up: the Transitional Cabinet of the Government of East Timor and the National Council. This reform, which laid the foundations for the first co-participatory transitional government in East Timor, transformed East Timor's former Governance and Public Administration function into the East Timor Transitional Administration (ETTA), whose powers included sharing a number of executive duties with UNTAET - among them, formulation of government policies and programs (UTAET, 14 jul. 2000a).

The ETTA radically changed the criterion of participation during UNTAET's administration (Beauvais, 2001), extending participation beyond political parties, to include geographic units and civil society organizations, as well as broadening the scope of decision-making mechanisms (it negotiated both legislative and executive policy and strategy proposals). With administrative authority spanning both central government and 13 districts, the ETTA formed a prototype national government. Timorese citizens were recruited into the civil service at various different levels, gradually replacing the foreigners who occupied key positions in government (UNTAET, 14 jul. 2000a).

Meanwhile, the 33-member National Council was based on a parliamentary-type system. ${ }^{4}$ It had the power to suggest and amend the content of regulations issued by UNTAET, as well as to summon any member of ETTA to provide further clarifications. Nonetheless, the representative of the transitional administration always retained the power to veto decisions "on the basis of substantial evidence" (UNTAET, 14 jul. 2000b, p.5) - and to replace members of both ETTA and the National Council itself.

This new arrangement made it possible to set a timeframe leading to the formation of a future autonomous government: parliamentary elections to a Constituent Assembly (August, 2001), drafting and approval of a National Constitution (March, 2002), presidential elections (April, 2002), and the transfer of power from UNTAET to the new independent government (May, 2002).

In August 2001, national elections to choose members of the Constituent Assembly redefined the interplay of political forces in Timor. The CNRT coalition unraveled: each party ran separately in the parliamentary elections, with FRETILIN and UDT taking most votes (Walsh, abr. 2001). On the basis of the results of these first free elections, in September 2001, UNTAET restructured the government in keeping with the will of the people.

A key feature of the second co-participatory, transitional government of East Timor was a Council of Ministers, consisting of one chief minister, ministers and vice-ministers, and secretaries of State. A Ministry of Health was set up to replace the Interim Health Authority. This composition for the future national government gave UNTAET the space it needed, at least until the official handover of governing authority, to continue to invest in building national capabilities for oversight of the actions and decisions of the different various ministers and secretaries. 


\section{The World Bank}

The World Bank had already been financing development projects in Timorese territory for the Indonesian government during its occupation of East Timor. With the advent of the CNRT and the headway made in negotiations with the United Nations on the independence referendum, the bank reallocated its funding and, from the beginning of 1999, was raising donations for a support fund to maintain a UN Mission in East Timor. In April 1999, the bank created a specific portfolio for East Timor and, in cooperation with the University of Columbia, conducted a survey on the economic situation and poverty there (Cliffe, 2003).

On September 29, 1999, once the conflict triggered by the referendum results was over, UNTAET administrator, Sérgio Vieira de Mello, and the Timorese leadership, represented by Xanana Gusmão and José Ramos Horta, met in Washington with the group known as the "friends of East Timor" (Rohland, Cliffe, nov. 2002, p.3), during the annual meeting of the World Bank and IMF, which approved "the creation of a Trust Fund to finance reconstruction and emergency recuperation programs in East Timor" (World..., 29 set. 1999, p.11).

In November 1999, the first Joint Assessment Mission (JAM), a multi-sector body led by the World Bank, arrived in East Timor to identify the country's needs. The "joint" nature of this mission was clear from the parity in the number of its members and by the inclusion of technical representatives from five donor countries (Cliffe, 2003). The mission was composed in such a way that the final results of the report would not necessarily represent the views of the World Bank, nor those of other agencies, but would constitute technical recommendations as input to finding solutions to the situation in the country. After each JAM, the donors met to discuss the mission report and decide what steps to take next.

The support that UNTAET received enabled it to establish the structures needed to guarantee Timorese political and administrative participation and, at the same time, to contract international personnel to assist in various aspects of executing and managing the process. The Timorese economy, which was devastated in 1999, began to recover with an injection of US dollars made possible by the UNTAET administration and by sectorial projects financed directly by the World Bank. The purchasing power of this new "workforce" led to significant growth in the country's commerce and service sectors (Rocamora, 2005).

In keeping with the institutional ideas and policies explicit in its 1990 World Development Report, the World Bank development strategy for East Timor hinged on balancing provision for basic needs, sustainable recovery of the private sector and strong governance structures, as a way of reducing the high poverty rates in the country (World..., 15 jun. 2001). From the model adopted to coordinate the rehabilitation and reconstruction projects, JAMs and donor meetings, it was clear to the Timorese people that the World Bank was the driving force that would lead them to independence and development (Davis, 2010).

\section{The architecture of foreign aid and international cooperation}

Reconstruction aid for East Timor rested fundamentally on two pillars: the Trust Fund for East Timor (TFET) and the Consolidated Fund for East Timor (CFET). By December 2001, the CFET, administered by UNTAET, had raised US\$ 54 million, which were used mainly to cover 
the recurrent costs of national government institutions (Alonso, Brugha, 2006). The TFET, administered by the World Bank, paid the costs of physical reconstruction and international technical assistance.

In September 1999, the Bank drafted a document containing essential elements for a plan to finance the reconstruction of East Timor (World..., 29 set. 1999), which recommended: (1) establishing democratic institutions and policies; (2) recuperating local infrastructure and restoring public service provision; (3) financing community-based projects; and (4) restoring economic activities, with special emphasis on agriculture, banking and private enterprise. It also recommended Timorese participation in the reconstruction process, a system of coordination among the various donors to East Timor (donor meetings) and the first JAM, which was held in 1999, over a period of three weeks (World..., 29 set. 1999). The JAM was a "supra-agency" event, which brought together technicians from a range of organizations and agencies, both multilateral (Asiatic Development Bank, PNUD, UNHCR, UNICEF, WHO) and bilateral (European Union, Australia, Japan, Portugal, the United Kingdom, USAID), in addition to the Timorese members. ${ }^{5}$

This first JAM, like all that followed, had a working methodology for the health sector: the parity group of health professionals made field trips and met with health personnel working at the facilities visited. At the end of each mission, they organized an "extended workshop" and only afterwards prepared their assessment and recommendations report. These reports, which formed the basis for donor meetings, used a standard template comprising a situation analysis (including financial aspects), a survey of priorities and recommendations.

The donor meetings, called to discuss and approve the JAM recommendations, followed the same format used at international meetings: three days of sessions, presentations of workgroup reports by sector, plenary discussions, and presentation of the final recommendations. Silva (2005), who carried out a detailed analysis of these meetings for East Timor, found they had an internal logic that served as a "mechanism for cosmological renewal used by the development partners and Timorese government representatives to reproduce the cooperation system they had forged" (p.40). Silva sees the donor meetings (informed by the JAMs) as landmark events expressing the modus operandi of international aid during the East Timor reconstruction process. During the period considered here (1999 to 2002) there were six JAMs and six donor meetings. The Timorese people understood that cooperation from the international community was essential to their country's reconstruction. For their part, the international community also had an interest in building the new State, as well as in securing new opportunities for cooperation and other relationships. The two discourses expressed common, though not necessarily convergent, interests and at that particular stage were essential to ensure that the coordination frameworks agreed between the parties functioned. In one way or another, the commitments were always renewed at each meeting.

The donors always made it clear that, after independence, once East Timor had been recognized by the United Nations, it should complete certain bureaucratic procedures to submit its application for membership of both the United Nations and the World Bank and IMF and that, after that procedure, the parties would have to re-discuss new loan arrangements.

The report on the first JAM, presented at the Tokyo meeting of donors in December 1999, endorsed the need to set up substantial coordination arrangements and recommended 
that strong support by international technical assistance. During this JAM, the healthcare workgroup identified the necessary stages for rehabilitation of the health sector and planned for continuous expansion of basic healthcare services (World..., nov. 1999).

The report also presented a three-year budget proposal, totaling nearly US\$ 71 million (World..., nov. 1999). The TFET's total budget for East Timor for the same period was US\$ 178 million, from 11 donors (including the World Bank), which financed 22 projects (including healthcare projects). The project approval mechanisms sought to avoid duplication (Davis, 2010): each TFET project was covered by a specific agreement with provision to the effect that funds would be allocated only after "management units" had been set up to administer the projects and their financial implementation (World..., 23 jun. 2000, p.2). One of the measures proposed was to contract international experts to train Timorese technicians in the bank's specific guidelines. This recommendation also formed part of the East Timor Health Sector Rehabilitation and Development Projects (HSRDP I and II).

HSRDP I and II were financed by TFET I and TFET II respectively, and contained the proposal to develop a health policy for East Timor as a contractual clause. Accordingly, the first official mention of drafting a health policy proposal document for the East Timor was in the first TFET Grant Agreement signed by the authorized UNTAET representative and the authorized World Bank representative, in the presence of the official CNRT representative (World..., 23 jun. 2000). HSRDP I estimated 15 months (2000-2001) for implementation and HSRDP II, 33 months. Both programs kept to practically the same structure, based on two main endeavors: restoring access to basic healthcare services for the whole population, and developing district healthcare plans (including goals, targets, timeframes and assessment indicators) that would inform discussion of a process for developing the bases of a healthcare policy.

During implementation of HSRDP I, an agreement was reached with NGOs working in East Timor, placing them under the overall coordination of the Interim Health Authority (IHA) and reinforcing national political control of the health sector (Tulloch et al., 2003). In June 2000, the IHA put out a call for proposals for 12-month district healthcare plans (UNTAET/IHA, 9 jun. 2000). NGOs had three weeks to submit their proposals. Only one NGO was chosen per district, and would also be responsible for providing health services at this level. The official public tender document - which was extremely detailed, in English and approved unanimously by the international agencies and by the IHA - outlined the principles and minimum standards for health services at the three levels of care. Having these district health plan proposals prepared on the basis of guidelines and standards established by IHA was intended to ensure that healthcare could be introduced as quickly as possible at the district level, promoting the efficient use of available resources with the priority of ensuring the broadest possible health service coverage and improving technical capacitation among Timorese health professionals (Alonso, Brugha, 2006).

Timorese participation in these sectorial rehabilitation projects was limited to brief consultations with the CNRT over certain aspects of the national policy (Davis, 2010). The World Bank advised on project design, ensured that financial procedures followed its guidelines, decided what could and could not be financed, and stipulated procedures governing company contracts, and fund disbursement and transfer. 
A number of premises present in official World Bank discourse were clearly and explicitly reinforced at all donor meetings and the respective supporting documents. These included the need for East Timor, before becoming independent, to prepare a National Development Plan that would not only include certain economic principles, such as fiscal adjustment with a view to controlling Timor's future public deficit, but also take a clear position on poverty reduction, public-private partnerships and sustainable economic growth. Thus, the donors were always strongly in favor of the health sector's adopting a broad sectorial approach, using different funding sources for one single project and focused on a health system structure centered on district plans with minimum quality standards (World..., 15 jun. 2001).

\section{The first Timorese health policy proposal document}

The process of drafting the first health policy proposal document for East Timor began in November 2000, when the cabinet member for Social Affairs, responsible for the Interim Health Authority, set up a Health Policy Advisory Group in response to pressure from the World Bank, which insisted East Timor begin policy framing as a key challenge for the institutionbuilding process (World Bank/IDA, 3 nov. 2000). In February 2001, the group organized a seminar on health policy-making models for East Timor (ETTA/DHS, abr. 2001b). In order to facilitate the health policy formulation process, concurrently with the seminar and in conjunction with the Division of Health Services (DHS), a diagnostic survey was quickly made of the country's situation. Two documents were prepared: Stakeholder and situation analysis of health system at district level in East Timor: a new model of cooperation? (ETTA/DHS, abr. 2001a) and Health policy formulation in East Timor: a genuine Timorese participatory and interactive process (ETTA/DHS, abr. 2001b), which were subsequently used by the Ministry of Health.

In November 2001, the fifth JAM report insisted that East Timor meet its commitment under TFET II to draft a health policy proposal document by the end of 2002. By this time, the first parliamentary elections had been held in East Timor, resulting in a redefinition of local political arrangements, which helped align support for the Ministry of Health's drafting of the first policy proposal document.

The document was based on the principles and constituent elements of the two health sector rehabilitation and development programs. Its point of departure was a situation and problem assessment and it sought to set out a vision, a mission and values for the sector. The Ministry of Health should ensure a viable and sustainable health system whose goals would be to regulate the sector, promote community and partner participation, and foster inter-sector actions. These goals would be achieved by means of principles including equity, cultural sensitivity, ethics, solidarity and friendship. This document included separate reports by each of the six thematic sub-groups, but presented no budget plan.

\section{International technical cooperation in health in post-conflict situations}

The interrelationships between health and conflict and post-conflict situations are complex and varied. They extend far beyond the health sector and interconnect a range of variables 
that change with changing circumstances and the role that health system rehabilitation plays in reconstruction of the State.

Accordingly, it has to be understood that the formation of the State of East Timor and building governability are two sides of the same coin. Although both processes have occurred throughout the country's history, this study limits itself to conditions during the conflict and post-conflict period between 1999 and 2002, when - at one and the same time - military forces (UN peace-keeping troops) and the UN transitional administration (UNTAET) entered the region to lead the country's reconstruction process. This process was concomitant with, and enabled by, an enormous influx of foreign resources, resulting from strong international aid activity, in the form of capital flows (financial aid) and expertise (technical assistance).

Two key features of the UN transitional administration in East Timor were that: (1) the international intervention approved by the UN in East Timor was not requested by East Timorese government representatives, but resulted from political lobbying by Timorese in exile who had fled the conflict, and the request from the invading nation - Indonesia - and the former colonial power - Portugal - who were members of the United Nations; and (2) UNTAET wielded total political and administrative authority in the country during the transitional period, as demonstrated by the fact that the three powers (Executive, Legislative and Judiciary) were concentrated in the hands of the resident UN representative. UNTAET thus came into being with a dual mission that marked the role of the United Nations in East Timor: to administer the territory and to prepare national institutions to assume control of the State after independence (Leininger, 2006; Downie, 2007).

The legitimacy of UNTAET's "political authority" was grounded in negotiations among the various stakeholders involved in the process, who sought to delimit its scope and exercise power from their respective positions of influence (Beauvais, 2001).

Political reconstruction of the East Timorese State and the success of the United Nations mission presupposed not only settling the conflict, but managing international aid effectively and guaranteeing independence, by restoring power to the Timorese people, which could only be achieved by establishing and structuring institutions (legality) and the State apparatus (bureaucracy), which in turn depended on formulating national policies.

This process was crucially dependent on coordinating a plethora of national and international actors from different organizations and institutional cultures, and with diverse interests, attitudes and power resources. The limits on the mandate and power of a United Nations transitional administration were given by its ability both to build its own legitimacy in East Timor and to coordinate with the national elites and local leaders.

Although the World Bank and the United Nations worked together, the division of tasks between them placed UNTAET in the position of a "national government" that assured political and institutional order and kept apparatus of State functioning, while the World Bank was the outside funder, with a prominent, leading role in East Timor's economic and social reconstruction.

In this way, the World Bank's technical recommendations ultimately also became a form of political governance in that they strongly influenced government project and policy making. Unsurprisingly, the Timorese saw the World Bank as the most important international actor 
in the reconstruction and rehabilitation process, since it also pressured UNTAET to meet its contractual obligations.

A discussion about governability in the post-conflict context in East Timor does not rest on dependency theory assumptions, as argued by authors such as Frank (1967) and Amin (1976), according to whom East Timor, as one of the poorest countries in the world and in a state of post-conflict penury, was economically and politically dependent on global structures led by the world's wealthiest countries which, in turn, would influence Timorese national policies. The conditions that foster dependency status are not simply imposed by the stronger powers, but are given also by donors' position and support from national elites, which is what establishes the conditions and means by which power is exercised and legitimized (Hughes, 2009).

However, the Timorese elite were never on the defensive against interference by the international community; on the contrary, they sought to work politically to solve their internal differences so as to gain that community's support. Setting up the CNRT, in 1998, was the definitive step in this direction. In their relationships with international actors, the Timorese always endeavored to show they were proactive and had their own opinions (Silva, 2005). The national actors' attitude to UNTAET went hand in hand with their acceptance of the conditionalities and requirements laid down in the wording and execution of World Bank rehabilitation projects. When the national elites supported and accepted the authority of international actors in their country, they were in fact, seeking to control the flow of international aid in such a way as to guarantee their own political influence and to pave the way to independence (Hughes, 2009).

For the purpose of this study, the "Timorese elite" comprises various social groups that were economically and politically influential in East Timor, drawn not only from former strata of rural farmers, traders and politicians from colonial times, but also from political and military activists of the war of resistance against Indonesia. During the transitional period, the category "functionaries of the State apparatus" was a powerful group that constituted a "new elite," which included various different social classes - former Indonesian civil servants (trained under the same system as, or even at, Indonesian schools), civil servants from Portuguese colonial times, and other younger civil servants whose first working experience was during the transition period (Silva, 2005).

UNTAET's policy of sharing decision-making with the Timorese proved a successful strategy. On the one hand, it incorporated the political demands for joint governance and self-determination; on the other, it accelerated the process of "Timorizing" the transitional government (United..., 25 out. 1999). World Bank and UNTAET rhetoric on participation led to a strategy of decentralization, which broadened the transitional administration's support base and emphasized the districts' role in the process.

The aid system, which financed cooperation, was fundamental. These funds not only conferred power and prestige, they also situated international cooperation as a field of action for the greater good. Accordingly, the way aid was channeled and structured gained added significance, since the interrelations among the various different actors occurred in the intricate maze of international technical assistance, which thus constituted an arena of 
political disputes, permeated by fierce competition, where the "new" forced its way against the vestiges of the previous order and the resistance put up by traditional practices (Silva, 2005).

The World Bank's two main coordination and monitoring mechanisms for the reconstruction of East Timor - the JAMs and the donor meetings - constituted another field of relationship among national and international actors, rooted in the process of developing projects to be discussed and approved at the donor meetings. However, these projects were implemented at a pace, and to a degree, influenced by the dynamics of Timorese society, which was driven both by events in the process of political institutionalization and by power relations among levels of government. All these situations formed a network of loci of control that - whether supporting, controlling or resisting - always interfered in the country reconstruction process and, as a result, ultimately also influenced the health sector rehabilitation process.

The JAMs - in addition to their role in coordination and as a field for experimentation with coexistence among the international agencies - also provided an opportunity for the various actors operating in the field to meet and mediate. The donor meetings fulfilled an "important metalinguistic function [by fostering] replacement of the terms that make up the cosmology of the field of international cooperation when putting State-building into perspective" (Silva, 2005, p.85) and reinforced "value-ideas" such as human rights, poverty reduction, capacity building, combating corruption, stability, development promotion and so on. The "rituals" that developed during these meetings, performed by international and national actors, also helped "renew the modus operandi that permeated State-building in East Timor [and] is defined by, among other things, the ability of the local political and technical elite to shape an image of the country" (Silva, 2005, p.85). In this, they oscillated, one moment affirming its commitments and capacities in accordance with the "cosmology" of the international organizations, the next projecting images of social privation and the population's needs in order to ensure that foreign aid continued.

Missions, meetings, negotiations, personnel recruitment procedures, parliamentary elections and appointments of ministers and heads of department marked UNTAET's threeyear transitional administration. These elements and mechanisms interfered, with greater or lesser significance, in the participation by the various actors involved in this process and influenced the formulation of the national health policy document. The guidelines for using TFET resources were based on the Health Sector Rehabilitation and Development Projects (HSRDPs); therefore, the drafting of those projects played a mediatory role in course-setting for the Timorese healthcare system, as well as in development of a policy proposal for the sector.

The first JAM incorporated the Timorese technicians who, since the Melbourne Conference and the start of the UNTAET government (in 1999), had been discussing a proposal for health sector organization (setting up a universal national health system based on the principle that healthcare is a right of citizens) and held a seminar on health systems, with broad participation, including NGOs, from which a health sector workgroup resulted. These steps were important in the donor and World Bank strategy to, on the one hand, start building a national structure to conduct healthcare and, on the other, to design a joint proposal to rehabilitate the service system. Another outcome of this process was the Interim Health Authority, which had majority Timorese representation, including district representatives. 
The two health sector rehabilitation projects that emerged between 1999 and 2002 not only incorporated the JAM recommendations and constituted vehicles expressing the outcomes of negotiations among the actors and enshrined in the World Bank grant agreements, but also served as mechanisms to drive the structuring of a national coordination over the diversity of NGOs working in East Timor. None of this would have been possible without support from international technicians, in that the pressure of deadlines and poor local technical capacity to keep to World Bank timeframes rushed decision-making. The workshops and training seminars which proliferated during the whole period and used techniques revered by international organizations - problematizing, priority scheduling and participatory problemsolving - served as mechanisms for "homogenizing capacities," spreading ideas and building consensuses on the proposals (Lima, 2007).

These mechanisms are widely used in the international technical assistance field, because they interconnects two dimensions, the "pedagogical" and the "performatic." In other words, "before actually teaching anything important ... the attempt is to 'teach' a way of presenting oneself in the [various] contexts where these matters are considered, an etiquette of what it is to participate in them, a jargon and, more than a way of thinking, a way of expressing oneself and making concessions" (Lima, 2007, p.421). They can thus be seen as forms of training, but they leave the partner in dialogue uncomfortable and at a disadvantage in relations with the cooperation agency.

What one sees during negotiations (or "training") to prepare development projects is that the representation of the ideas involved never operates between equals and they constitute "spaces for intervention" (Rew, 1997). It is precisely here that the power of donors to induce operates and imposes itself, based on a rationale independent of the local realities, symbolized by technical studies and dense reports, but "veiled behind the rhetoric of partnership" (Mosse, 2005, p.40).

Would a longer timeframe solve the central problem of these asymmetries leveraged by the working methods employed? Hughes (2009) argues that, in situations where dependency is consented to and entered into by mutual agreement to the benefit of both sides, what might cause problems is precisely the possibility of the stronger party (namely the donors) imposing its ideology, which is also expressed in international technical assistance which functions as a "translator" among the different representations. Mosse (2005) examined various different interventions recommended by international agency representatives, concluding that the reason why many of them were guided less by the development needs of the country concerned, and more by the requirements of the international agencies and organizations which need to maintain good relations with the donor community. This is why it is not uncommon for development policies to play a role, in the recipient countries, that has more to do with legitimizing the ideas of the donors and international agencies than guiding the development they propose.

Added to this, the capacity-building approach used during the UN transitional administration period revealed another important issue: the use of English as the preferred language of international cooperation, while Portuguese was relegated to the status of national "political" language. In addition to communications problems, the use of English created a socio-linguistic divide among the Timorese. Many Timorese who returned from 
exile speaking English often ended up working for, or being remunerated by, ETTA-UNTAET or some other international agency (Silva, 2005). Since most of the civil servants recruited for the transitional administration were Timorese who had remained in the country during the period of occupation and spoke neither Portuguese nor English, but Bahasa from Indonesia, three very distinct divisions were created within Timorese society: (1) the older generation, who were more traditional and held political authority, spoke Portuguese; (2) a younger generation of "former exiles," who had administrative authority and some influence, spoke English and/or Portuguese; and (3) the youngest generation with less authority, who spoke only Bahasa.

At the district level, communication difficulties (further exacerbated by the linguistic question and "caste" differences among national technicians), the lack of training and understanding among both national and international health professionals (each with their own particular impediments) as regards the dynamics of aid to the sector, and practices related to Timorese traditions of legitimation, including political and ethnic differences and others, were at the same time additional difficulties and forms of resistance which, according to the rehabilitation project guidelines, were to be overcome by training.

Time and the professional attitudes of each of the actors involved were crucial. The main difficulty was ensuring that local professionals understood, assimilated and introduced new concepts and working practices into their daily routines, in such a short space of time. There was also little time for foreign technicians to adapt to, and involve themselves in the local way of life, in order to develop effective strategies for working and moving forward together. The timeframes, goals and products brought these two very distinct "universes" together, but were not sufficient to accomplish the intended change. Similarly, the meaning of the terms "community" and "civil society" is different in countries with non-European cultures, and that was certainly the case in East Timor, which still has a strongly active stock of traditional culture, which can establish ties of subordination and "patronage" or favor certain groups to the detriment of others, all of which influenced the process of constructing and setting up the institutions of State (Pouligny, 2005).

Drafting of the proposal document was postponed until after the process to elect the National Constituent Assembly, the concomitant inauguration of the Ministry of Health, and the appointment of district team leaders in 2001. There was constant tension between the attitudes of the international actors - especially the World Bank, under donor pressure, incisively demanding results - and the transitional government and its national political "allies."

The health policy proposal document was published in June 2002, after the first Timorese president had been elected and independence restored. It expressed clearly the context in which it had been drafted: it had to meet the donors' contractual requirements as regards sector rehabilitation and, at the same time, to deal with the national conjuncture of institutional reconstruction and transition of political and administrative power. It was not the ideal document, but the possible one and, more than that, it constituted fulfilment of one of the requirements demanded of the transitional Timorese government in the international agreements, largely guaranteeing that aid would continue during the period while independence was being restored (Anderson, 2003). The document developed some 
ideas, but did not stipulate exactly what the Ministry of Health should implement, nor how, where or by whom. It remained to set health sector priorities politically and to specify what action would be taken to meet those priorities and with what funds. It did, however, include and reiterate some of the tenets held and transmitted by the World Bank.

To its credit, it did, in a single policy proposal document, provide the different partners with "a preliminary view of the direction [it was intended] to give to the Ministry of Health's strategic policies" (RDTL, 2002, p.14). Also in 2002, in the preface to the National Development Plan (RDTL, maio 2002), the prime minister of the Democratic Republic of East Timor, Mari Alkatiri, recalled that the Timorese people had met their commitments. By demonstrating their agreement with development principles and guidelines advocated by the international organizations, the Timorese people were also calling for foreign aid to the country to continue.

\section{Final considerations}

Rehabilitation of countries in post-conflict situations is a process of transition to "peace" and the "normality" of life in society achieved with outside support in reconstructing these nations' socioeconomic and political structures. In that light, the reconstruction process becomes key to establis the conditions needed to assure the functioning of the "pacified" society (Okumu-Alya, 2010).

In the late twentieth century, mediation by international organizations in the reconstruction and rehabilitation of nation States and specific sectors (such as the health sector) occurred in a world context where the nexus had been restored between development and security (Kaldor, 2006; Richards, 2005). Policy making in countries affected by conflicts or natural disasters was seen as an important factor in guaranteeing security and reducing distrust (or possible resistance) from national groups by creating the conditions in which aid could be successful and the country at risk, develop.

Acceptance for outside proposals and ideas not only legitimizes the authority of the international agents in the domestic sphere, it also helps create a more sustainable climate for local institutions to attain good results and thereby enhance the legitimacy of the reconstructed State. In this way, both national and international institutional spheres ultimately benefit from the cooperation process.

In May 2002, the Democratic Republic of East Timor became the $184^{\text {th }}$ member of the United Nations and, consequently, a member of the World Bank and IMF. During the Statebuilding process in East Timor, both the United Nations and the World Bank played prominent roles, supported by a strong international cooperation structure in a broad range of social sectors, with a large contingent of advisors and consultants who collaborated in constructing national institutions and restoring "order."

Funding for the peace-keeping, administration and reconstruction operations in East Timor was administered by the World Bank, by consolidated funds and donor funds. The United Nations presence in East Timor was essential to guaranteeing the interaction between political stability and economic development, which are both required for the successful implementation of sector projects and policies. Rocamora (2005) notes that the UNTAET's departure in 2002 meant an enormous reduction in the inflow of foreign currency; together 
with increased energy consumption, aggravated by payment defaults, this caused public deficit to rise, leading East Timor's first post-independence government to increase taxes and adopt a policy of cost containment, as proposed by the World Bank. These measures generated public dissatisfaction and a significant opposition movement in the crisis of 2006.

The World Bank always played a strong role as an "instrument for circulating, internalizing and institutionalizing its main product: economic ideas and political prescriptions of what to do, how to do it, who should do it and for whom in matters of capitalist development" (Pereira, 2010, p.276). Construction of the Timorese State occurred at a time when the Bank's structural adjustment doctrines were beginning to give way to policies that brought the State back into the development process. This conjuncture left its imprint on the rehabilitation process in various sectors in East Timor and was strongly supported by the World Bank's new policies, known as the "second generation" conditionalities, relating to issues of democracy, good governance and human rights (Siitonen, 2010). However, application of these ideas still rested on the basic premises of strengthening public-private partnerships and combating poverty.

In this respect, international cooperation played an important part in building national institutions and the Timorese State itself, where the political dimension of the "government" adopted by UNTAET and by the World Bank during the transition period conditioned the final model of the future national administration. That modeling occurred on the basis of implicit power mechanisms in various different spheres. International technical cooperation was directed primarily to capacity building, to spaces with potential for disseminating "ways of doing" and propagating symbols and values related to the culture of the international organizations (Silva, 2005; Lima, 2007; Valente, 2010; Almeida et al., 2010).

Development projects seek to maintain themselves as coherent ideas (systems of representations) and as operational systems for implementation of those ideas. Guaranteed success in the project outcome is connected with implementing these ideas and therefore depends not on the ability to transform designs into reality, but rather on the origin of the ideas (Mosse, 2005). The further the representation system of ideas is from the representation system of those who are to implement them, the more difficult it is to achieve success. Even in a situation where dependency is consensual and agreed to the benefit of both sides, what may cause problems is precisely the possibility of ideological imposition by the stronger party, namely the donors, as expressed in international technical assistance which, functioning as a "translator" between different representations, runs the risk of adopting rigid standards that do not adapt to the recipient countries (Hughes, 2009).

It is not rare for knowledge and expertise developed by outside agents to be seen as a mechanism for influencing or even interfering in national decision-making. In some cases, however, as in East Timor, technical assistance can be an option accepted by national groups as a political strategy and not as external coercion or imposition (Valente, 2010). In the situation East Timor found itself in between 1999 and 2002, not many options were available to the national political elite. The deadlines imposed in the grant agreements were an important factor in the power relationships that permeated not only the technical cooperation process, but also preparation of East Timor's first national health policy proposal. 
Administration of the Trust Fund in East Timor was often a bone of contention between the World Bank and representatives of sectors of society, due mainly to the low level of national participation in decisions related to peace and reconstruction aid funding (Davis, 2010). Both donors and the Bank were concerned about the possibility of misuse of funds or even corruption. Even though this concern is present in practically all external development aid, what changes in severe and acute conflict and post-conflict situations is the recipient State's weak ability to exercise its sovereignty, because it is still under construction. This justification, instead of opening the door to participatory experimentation, seemed to offer "the rationale, or excuse, for strengthened World Bank and donor control" (Davis, 2010, p.200).

The process of "Timorizing" the UNTAET government was a political strategy that functioned as a bargaining chip when under pressure from the national elites, whose power pervaded all levels of Timor society. UNTAET's option for a participatory approach made it easier to strengthen its decision-making capacity at sub-national administrative levels. On the other hand, although the Timorese authorities in the co-participatory transitional government had set up a Health Policy Advisory Group, practically all the initiatives to start (and re-start) the process that would make it possible to formulate a health policy for East Timor arose from international technical assistance. However, it was only after the parliamentary elections that, working under pressure and to tight (four-month) deadlines, the new minister of Health took the lead in the process and carried it through to the end, drafting and arranging publication of the final document. Accordingly, despite the pressure, it was the Timorese who set the pace of the decision-making process to formulate this policy, linking it in turn to their affirmation of national authority in the health sector. Cooperation relationships also embody power relationships, and the exercise of power changes or reflects conjunctural moments.

Preparation of the first national health policy proposal document, occurring in this process and in this dynamic, served to reinforce the element of trust among the various actors, and boosted the capacity of each one in the process. This was therefore the result of the relationship between the ideas and conditionalities of the international organizations, embodied in technical cooperation and expressed through the international agency control mechanisms; but it was also the result of interaction with the national political elite (which, in turn, also interacted with the various local leaderships). It was from this intricate network of relationships that the first health sector policy proposal for East Timor emerged - and it remained in force until 2010. Although components and strategies incorporated into this document by Timorese followed international standards, the process of drafting the document legitimized the national health authority to its international partners, by fulfilling the conditionalities stipulated, and established that authority in the eyes of the nation's government and population after the elections.

Analyzing this formulation process helped to understand how mechanisms of induction and technical cooperation mediated by international organizations interrelate with the national sphere at particular conjunctures where diverse national and international political arenas interlace at different times and places of negotiation. To some extent, national actors consent to this dynamic because of their extreme dependence on external aid. Analyzing that 
process entailed understanding the architecture of aid to the health sector in East Timor, as well as the dynamic established by the United Nations and the World Bank in this specific instance of a post-conflict situation.

\section{AKNOWLEDGEMENTS}

This paper was prepared and translated into English with support from the project "International relations and health: foreign policy and international cooperation in health," financed by Fundação Carlos Chagas Filho de Amparo à Pesquisa do Estado do Rio de Janeiro. We are also grateful to CNPq for its support through a research grant (scholarship) to Celia Almeida.

\section{NOTES}

* This article summarizes arguments developed in detail in the doctoral thesis "Health policy making in a post-conflict situation: the process of preparing the first document of health policy proposals for East Timor, 1999 to 2002" ("Formulação de políticas de saúde em situação pós-conflito: o processo de elaboração do primeiro documento propositivo de uma política de saúde para o Timor Leste, 1999 a 2002 "), defended by Luiz Eduardo Fonseca at ENSP/Fiocruz in 2011 under the supervision of Celia Almeida.

${ }^{1}$ The literacy rate rose from $10 \%$ in 1975 , to $48 \%$ in 1999 . Education establishments increased from a total of 49 schools in 1975, to 66 kindergartens, 788 primary schools, 114 secondary schools (of which 37 were technical education schools) and 17 higher education colleges in 1999. Thus, the number of students rose from a total of 14,000 in 1975, to 30,000 enrolled in just the first year of elementary school in 1998 (Pedersen, Arneberg, 1999).

${ }^{2}$ In 1998, the Timorese health system's physical structure comprised: one central hospital, 11 regional hospitals, 29 health facilities with beds, seventy health facilities beds, 305 health posts, 19 pharmacies and two central laboratories, seven specialist doctors (of whom one was Timorese), 134 general practitioners (25 of them Timorese), 1,124 nursing auxiliaries, 58 oral hygiene nurses and 383 trained midwives (Pedersen, Arneberg, 1999).

${ }^{3}$ In 1975 , with a total population of around 600,000 inhabitants, East Timor had a birth rate of almost five children per mother, a life expectancy of around 46 years, an infant mortality rate of 140 per 1000 and a mortality rate for children up to age five of 240 per 1000 (Pedersen, Arneberg, 1999). In 1998, before the conflict, and with a population of around 800,000 inhabitants, infant mortality had fallen to 60 per 1000 and the mortality rate for children under five to eighty per 1000 (Pedersen, Arneberg, 1999).

${ }^{4}$ Seven CNRT representatives, three representative from other political parties, one representative from each of the 13 districts and one representative from each of the following social organizations: the Catholic Church, Protestant Christian organizations, the Islamic community, women's and student organizations, NGO forums, professional associations, the rural community, businessmen and workers (UNTAET, 14 jul. $2000 \mathrm{~b}$ ).

${ }^{5}$ The first JAM comprised 25 international members, plus 25 Timorese members appointed by the CNRT, with two coordinators - one appointed by the World Bank and the other by the CNRT - totaling 52 mission members. The health sector workgroup was formed by four people: one professional from the World Health Organization, one from the United Kingdom's Department for International Development, and two doctors from the CNRT (one of whom, Nelson Martins, was East Timor's Health minister from 2009 to 2012).

\section{REFERENCES}

AGÊNCIA...

Agência Geral do Ultramar. Timor: pequena monografia. Lisboa: Agência Geral. 1966.

ALMEIDA, Celia et al.

A concepção brasileira de "cooperação Sul-Sul estruturante em saúde". Revista Eletrônica de Comunicação, Informação e Inovação em Saúde, v.4, n.1, p.25-35. Disponível em: http://www. reciis.icict.fiocruz.br/index.php/reciis/article/ view/343/527. Acesso em: 6 out. 2014. 2010.
ALONSO, Alvaro; BRUGHA, Ruairi.

Rehabilitating the health system after conflict in East Timor: a shift from NGO to government leadership. Health Policy and Planning, v.21, n.3, p.206-216. 2006.

AMIN, Samir.

Unequal development: an essay on the social formations of peripheral capitalism. New York: Monthly Review Press. 1976. 
ANDERSON, Tim.

Self-determination after independence: East Timor and the World Bank. Portuguese Studies Review, v.11, n.1, p.169-185. 2003.

ANVERSA, Gerson Luís Albrecht.

Não à barbárie! A independência de Timor-Leste. Disponível em: http://www.nao-til.com.br/nao68/timor.htm. Acesso em: 10 out. 2009. s.d.

BEAUVAIS, Joel C.

Benevolent despotism: a critique of UN statebuilding in East Timor. New York University Journal of International Law and Politics, v.33, n.4, p.1101-1178. 2001.

BRINKERHOFF, Derick; BRINKERHOFF, Jennifer. Governance reforms and failed states: challenges and implications. International Review of

Administrative Sciences, v.68, n.4, p.511-531. 2002.

CLIFFE, Sarah.

The joint assessment mission and reconstruction in East Timor. In: Fox, James J; Soares, Dionisio Babo (Ed.). Out of the ashes: destruction and reconstruction of East Timor. Camberra: ANU E Press. p.233-242. Disponível em: http://press. anu.edu.au/wp-content/uploads/2011/05/c16. pdf. 2003.

CNRT.

Conselho Nacional da Resistência Timorense. Statement of the National Council of Timorese Resistance. Disponível em: www.mail-archive. com/leftlink@vicnet.net.au/msg01050.html. Acesso em: 10 set. 2010.9 abr. 1999.

CNRT.

Conselho Nacional da Resistência Timorense. Carta magna de liberdades, direitos, deveres e garantias do povo de Timor-Leste. Peniche: Convenção Nacional Timorense na Diáspora. abr. 1998a.

CNRT.

Conselho Nacional da Resistência Timorense. Unir para resistir: resistir é vencer: moção de orientação. Peniche: Convenção Nacional Timorense na Diáspora. abr. 1998b.

DAVIS, Thomas W.D.

Reconstructing Timor-Leste: the World Bank's trust fund for East Timor. In: Understanding Timor-Leste. Australia: Timor Leste Studies Association Publishers. p.196-201. 2010.

DOWNIE, Sue.

UNTAET: state-building and peace-building. In: Kingsburry, Damien; Leach, Michael (Coord.). East Timor: beyond independence. Australia: Monash University Press. p.29-42. 2007.

DUFFIELD, Mark.

Global governance and the new wars: the merging of development and security. London: Zed Books. 2001.
ETTA/DHS.

East Timor Transitional Administration/Division of Health Services. Stakeholder and situation analysis of health system at district level in East Timor: a new model of cooperation? Díli: DHS. abr. 2001a.

ETTA/DHS.

East Timor Transitional Administration/Division of Health Services. Health policy formulation in

East Timor: a genuine Timorese participatory and interactive process. Díli: DHS. abr. 2001b.

FRANK, André Gunder.

Capitalism and underdevelopment in Latin America. New York: Monthly Review Press. 1967.

GUNN, Geoffrey C.

A ocupação indonésia de Timor-Leste: lições e legados para a construção do Estado da nova nação. In: Silva, Kelly Cristiane da; Simião, Daniel Schroeter (Org.). Timor-Leste por trás do palco: cooperação internacional e a dialética da formação do Estado. Belo Horizonte: Ed. UFMG. p.40-62. 2007.

HUGHES, Caroline.

Dependent communities: aid and politics in Cambodia and East Timor. New York: Southeast Asia Program Publications, Cornell University. 2009.

ICISS.

International Commission on Intervention and State Sovereignty. The responsibility to protect: report of the International Commission on Intervention and State Sovereignty. Ottawa: International Development Research Centre. 2001.

KALDOR, Mary.

New and old war. Cambridge: Polity Press. 2006.

KONDOCH, Boris.

The United Nations administration of East Timor. Journal of Conflict and Security Law, v.6, n.2, p.245-265. 2001.

KOPONEN, Juhani.

The security-development nexus, state fragility and state building. In: Alava, Henni (Ed.). Exploring the security-development nexus: perspectives from Nepal, Northern Uganda and "Sugango". Helsinki: Ministry for Foreign Affairs of Finland. p.23-42. 2010.

LEININGER, Julia.

Democracy and UN peace-keeping: conflict resolution through State building and democracy promotion in Haiti. In: Wolfrum, R.; Bogdandy, A. (Ed.). Max Planck Yearbook of UN Law. v.10. Heidelberg: Martinus Nijhoff Publishers. p.465530. 2006. 
LIMA, Antonio Carlos de Souza.

Notas (muito) breves sobre a cooperação técnica internacional para o desenvolvimento. In: Silva, Kelly Cristina; Simião, Daniel Schroeder (Org.). Timor-Leste por trás do palco: cooperação internacional e a dialética da formação do Estado. Belo Horizonte: Editora UFMG. p.417-425. 2007.

MACHADO, José Barbosa.

Timor Loro'Sae e o pós-colonialismo. Disponível em: http://alfarrabio.di.uminho.pt/vercial/zips/ machad02.rtf. Acesso em: 22 jan. 2011. s.d.

MARTIN, Ian.

Autodeterminação em Timor-Leste: as Nações Unidas, o voto e a intervenção internacional. Trad. Inês Castro. Lisboa: Quetzal. 2001.

MOSSE, David.

Cultivating development: an ethnography of aid policy and practice. New York: Pluto Press. 2005.

NINER, Sarah.

A long journey of resistence: the origins and struggle of the CNRT. Bulletin of Concerned Asian Scholars, v.32, 1-2. 2000.

O'CONNOR, Sue.

New evidence from East Timor contributes to our understanding of earliest modern human colonization east of the Sunda Shelf. Antiquity, v.81, n.313, p.523-535. 2007.

OECD/DAC.

Organisation for Economic Co-operation and Development/Development Assistance Committee. State building in situations of fragility. Paris: OECD/DAC. 2008.

OKUMU-ALYA, Fabius.

Reconciliation and post-conflict reconstruction in Northern Uganda. In: Alava, Henni (Ed.). Exploring the security-development nexus: perspectives from Nepal, Northern Uganda and "Sugango". Helsinki: Ministry for Foreign Affairs of Finland. p.81-110. 2010.

PEREIRA, João Marcio Mendes.

O Banco Mundial e a construção políticointelectual do "combate à pobreza". Topoi, v.11, n.21, p.260-282. 2010.

PEREIRA, Luís T.

Relatório da participação na Conferência sobre Planejamento Estratégico para Timor-Leste. Lisboa. 8 maio 1999.

PEDERSEN, Jon; ARNEBERG, Marie (Ed.). Social and economic conditions in East Timor. New York: Columbia University; Oslo: Fafo Institute of Applied Social Science. Disponível em: http://www.fafo.no/pub/rapp/929/easttimor. PDF. Acesso em: 18 jun. 2010. 1999.
POULIGNY, Beatrice.

Civil society and post-conflict peacebuilding: ambiguities of international programmes aimed at building "new" societies. Security Dialogue, v.36, n.4, p.495-510. 2005.

RDTL.

República Democrática de Timor-Leste. Constituição da República Democrática de Timor Leste. Díli: RDTL. 2002.

RDTL.

República Democrática de Timor-Leste. Plano de desenvolvimento nacional. Díli: RDTL/Comissão do Plano. maio 2002.

REW, Alan.

"The donors" discourse: official social development knowledge in the 1980s. In: Grillo, Ralf D.; Stirrat, Roderick L. (Ed.). Discourses of development: anthropological perspectives. Oxford: Berg. p.81-106. 1997.

RICHARDS, Paul (Ed.).

No peace, no war: an anthropology of contemporary armed conflicts. Oxford: James Currey. 2005.

ROCAMORA, José Antonio.

Timor Oriental tras la ocupación indonesia. Revista CIDOB d'Afers Internacionals, n.69, p.173-194. 2005

ROHLAND, Klaus; CLIFFE, Sarah.

The East Timor reconstruction program: successes, problems and tradeoffs. Working Papers. Paper n.2. Washington, D.C.: World Bank. Disponível em: http://pascal.iseg.utl. pt/ cesa/WP2EastTimor.pdf. Acesso em: 10 out. 2014. nov. 2002.

SCHOUTEN, Maria Johanna.

A prática de um ideal: "civilização" e a presença colonial portuguesa em Timor-Leste. In: Silva, Kelly Cristiane da; Simião, Daniel Schroeter (Org.). Timor-Leste por trás do palco: cooperação internacional e a dialética da formação do Estado. Belo Horizonte: Humanitas; Ed. UFMG. p.27-39. 2007.

SEIXAS, Paulo Castro.

Dualismo, violência mimética e cultura da tradução: a crise em Timor-Leste. In: Silva, Kelly Cristiane da; Simião, Daniel Schroeter (Org.). Timor-Leste por trás do palco: cooperação internacional e a dialética da formação do Estado. Belo Horizonte: Humanitas; Ed. UFMG. p.63-94. 2007.

SIITONEN, Lauri.

The role of development assistance in fragile situations. In: Alava, Henni (Ed.). Exploring the security-development nexus: perspectives from Nepal, Northern Uganda and "Sugango". 
Helsinki: Ministry for Foreign Affairs of Finland. p.43-52. 2010.

SILVA, Kelly Cristiane.

Paradoxos da autodeterminação: a construção do Estado nação e práticas da ONU em TimorLeste. Tese (Doutorado em Antropologia) Universidade de Brasília, Brasília. 2005.

TAYLOR, John G.

East Timor: the price of freedom. Australia: Pluto Press. 1999.

TULLOCH, Jim et al.

Initial steps in rebuilding the health sector in East Timor. Washington, D.C.: The National Academies Press. Disponível em: http://www. nap.edu/openbook.php?record_id=10702. Acesso em: 10 out. 2009. 2003.

\section{UNITED...}

United Nations. Security Council. Report of the secretary-general on the United Nations Transitional Administration in East Timor. Document n.S/2000/53. Disponível em: http:// daccess-dds-ny.un.org/doc/UNDOC/GEN/ N00/261/62/PDF/N0026162.pdf?OpenElement. Acesso em: 17 jan. 2011. 26 jan. 2000.

UNITED...

United Nations. Security Council. Resolution 1272. Disponível em: http://www.un.org/en/ peacekeeping/missions/past/etimor/docs/9931277E. htm. Acesso em: 10 out. 2014. 25 out. 1999.

\section{UNTAET.}

United Nations Transitional Administration in East Timor. Regulation n.2000/23. On the establishment of the Cabinet of the Transitional Government in East Timor. Díli: Untaed. Disponível em: http://www.un.org/en/ peacekeeping/missions/past/etimor/untaetR/ Reg2300E.pdf. Acesso em: 10 out. 2014. 14 jul. 2000a.

\section{UNTAET.}

United Nations Transitional Administration in East Timor. Regulation n.2000/24. On the establishment of a National Council. Díli: UNTAED. Disponível em: http://www.jornal.gov. tl/lawsTL/UNTAET-Law/Regulations\%20English/ Reg2000-24.pdf. Acesso em: 1 out. 2014. 14 jul. $2000 \mathrm{~b}$.

\section{UNTAET.}

United Nations Transitional Administration in East Timor. Regulation n.1999/2. On the establishment of a National Consultative
Council. Díli: Untaed. Disponível em: http:// www.un.org/en/peacekeeping/missions/past/ etimor/untaetR/etreg2.htm. Acesso em: 1 out. 2014. 2 dez. 1999.

\section{UNTAET/IHA.}

United Nations Transitional Administration in East Timor/Interim Health Authority. Request for proposals for district health plans. Díli: Untaet/ IHA. 9 jun. 2000.

VALENTE, Renata Curcio.

A GTZ no Brasil: uma etnografia da cooperação alemã para o desenvolvimento. Rio de Janeiro: E-papers. 2010.

WALSH, Pat.

East Timor's political parties and grouping: briefing notes. Melbourne: Australian Council for Overseas Aid. abr. 2001.

WATERS, Hugh; GARRET, Brinnon; BURNHAM, Gilbert.

Rehabilitating health systems in post-conflict situations. Research Paper n.2007/6. United Nations University and World Institute for Development Economics Research. 2007.

WORLD...

World Bank. Press release of the Fourth Donors Meeting for East Timor. Canberra. 15 jun. 2001.

WORLD...

World Bank. Press release of the Second Donors Meeting for East Timor. Lisbon. 23 jun. 2000.

WORLD...

World Bank. Background paper prepared for the information meeting on East Timor, East Asia and Pacific region of the World Bank. Washington, D.C.: World Bank. 29 set. 1999.

WORLD...

World Bank. East Timor, building a nation: a framework for reconstruction and development: health and education background paper.

Washington, D.C.: Joint Assessment Mission to East Timor. nov. 1999.

\section{WORLD BANK/IDA.}

World Bank/International Development Association. Memorandum of the President of the International Development Association (IDA) to the Executive Directors on a Transitional Support Strategy of the World Bank Group for East Timor. Washington, D.C.: World Bank/IDA. 3 nov. 2000. 